\title{
Management Options and Factors Affecting Control of a Common Waterhemp (Amaranthus rudis) Biotype Resistant to Protoporphyrinogen Oxidase-Inhibiting Herbicides
}

\author{
Dana B. Harder, ${ }^{1}$ Kelly A. Nelson, ${ }^{2}$ and Reid J. Smeda ${ }^{3}$ \\ ${ }^{1}$ Production and Processing Technology, Syngenta Seeds Inc., Washington, IA 52353, USA \\ ${ }^{2}$ Division of Plant Sciences, University of Missouri, Novelty, MO 63460, USA \\ ${ }^{3}$ Division of Plant Sciences, University of Missouri, Columbia, MO 65211, USA
}

Correspondence should be addressed to Kelly A. Nelson, nelsonke@missouri.edu

Received 14 June 2012; Revised 14 July 2012; Accepted 17 July 2012

Academic Editor: Patrick J. Tranel

Copyright ( $) 2012$ Dana B. Harder et al. This is an open access article distributed under the Creative Commons Attribution License, which permits unrestricted use, distribution, and reproduction in any medium, provided the original work is properly cited.

\begin{abstract}
Repeated use of protox-inhibiting herbicides has resulted in a common waterhemp (Amaranthus rudis Sauer) biotype that survived lactofen applied up to 10 times the labeled rate. Field and greenhouse research evaluated control options for this biotype of common waterhemp. In the field, PRE applications of flumioxazin at $72 \mathrm{~g}$ ai ha $^{-1}$, sulfentrazone at $240 \mathrm{~g}$ ai ha $\mathrm{ha}^{-1}$, and isoxaflutole at $70 \mathrm{~g}$ ai ha ${ }^{-1}$ controlled common waterhemp $>90 \%$ up to 6 weeks after treatment. POST applications of fomesafen at $330 \mathrm{~g}$ ai $\mathrm{ha}^{-1}$, lactofen at $220 \mathrm{~g}$ ai ha ${ }^{-1}$, and acifluorfen at $420 \mathrm{~g}$ ai ha ${ }^{-1}$ resulted in $<60 \%$ visual control of common waterhemp, but differences were detected among herbicides. In the greenhouse, glyphosate was the only herbicide that controlled protox resistant waterhemp. The majority of herbicide activity from POST flumioxazin, fomesafen, acifluorfen, and lactofen was from foliar placement, but control was less than $40 \%$ regardless of placement. Control of common waterhemp seeded at weekly intervals after herbicide treatment with flumioxazin, fomesafen, sulfentrazone, atrazine, and isoxaflutole exceeded $85 \%$ at 0 weeks after herbicide application (WAHA), while control with isoxaflutole was greater than 60\% 6 WAHA. PRE and POST options for protox-resistant common waterhemp are available to manage herbicide resistance.
\end{abstract}

\section{Introduction}

Common waterhemp (Amaranthus rudis Sauer) is a problematic weed in corn (Zea mays L.) and soybean (Glycine max L. Merr) production systems throughout the central United States $[1,2]$. In Missouri, common waterhemp is considered the worst weed to control among producers [3]. Common waterhemp has adapted to a range of growing conditions and crop production systems due to prolific seed production [4-6], competitiveness [7-9], genetic diversity, and herbicide resistance [10-13].

Common waterhemp is resistant to multiple herbicides that cover six modes of action. Initially, resistance to triazine herbicides [14] was documented in the Midwestern U.S., followed by resistance to acetolactate-synthase- (ALS-) inhibiting herbicides $[15,16]$. As resistant populations became more frequent, a population of common waterhemp exhibited multiple-resistance to both triazine and ALS-inhibiting herbicides [10]. The ineffectiveness of ALS-inhibiting herbicides led to broad adoption of protoporphyrinogen-oxidase (Protox-) inhibiting herbicides. However, continuous usage resulted in common waterhemp biotypes resistant to POST applications of acifluorfen and lactofen in Illinois, Missouri, and Kansas [8, 9, 12, 17]. Li et al. [17] determined that a resistant biotype of common waterhemp in Missouri required a 44-fold higher rate of lactofen to achieve similar reduction in plant biomass compared to susceptible plants. Over 30\% of the fields in Northeast Kansas were reported resistant to a POST application of protox-inhibiting herbicides [12].

Protox-inhibiting herbicides have been used commonly for PRE and POST weed control in corn and soybean [18-21]. Structurally distinct families classified as 
protox-inhibiting herbicides include diphenyl ethers, $\mathrm{N}$ phenylphthalimides, oxadiazoles, oxazolidinediones, phenylpryrazoles, pyrimidindiones, thiadizaoles, and triazolinones [22]. Commonly used herbicides for residual management of common waterhemp in soybean include sulfentrazone or flumioxazin, with POST herbicides composed of the diphenyl ethers acifluorfen, fomesafen, and lactofen [23, 24]. However, the adoption of glyphosate-resistant crops resulted in a sharp decrease in the use of protox herbicides, likely slowing the selection of additional resistant populations.

Recently, the extensive reliance on glyphosate for weed management in soybean has resulted in the selection of waterhemp (Amaranthus spp.) populations exhibiting resistance [25]. In greenhouse studies, common waterhemp seedlings from field-collected seed at two Missouri locations showed a level of resistance between 9- and 19-fold greater than susceptible plants. Surprisingly, plants were crossresistant to both ALS- and protox-inhibiting herbicides.

Protox-inhibiting herbicides show varying levels of soil persistence. The PRE herbicides, flumioxazin and sulfentrazone, have a soil half-life of 11.9-17.5 and 121-302 d, respectively [22]. The POST herbicides acifluorfen, fomesafen, and lactofen have a soil half-life of $14-60,100$, and $3 \mathrm{~d}$, respectively, with fomesafen persisting longer under aerobic conditions [22]. Flumioxazin, fomesafen, and sulfentrazone are relatively mobile in the soil with plant roots absorbing and transporting herbicide through the xylem $[22,26]$. However, acifluorfen and lactofen have shown limited plant movement [22].

Research is needed to identify effective alternatives to control waterhemp populations resistant to multiple herbicide modes of action. The objectives of this research were to: (1) evaluate PRE and POST options for managing a population of common waterhemp with resistance to protox-inhibiting herbicides; (2) evaluate common waterhemp for multiple resistances to triazine, ALS-inhibiting, HPPD, and glyphosate herbicides; (3) determine how herbicide placement and soil persistence affects control of common waterhemp that is resistant to protox-inhibiting herbicides.

\section{Materials and Methods}

2.1. Field Experiment. Research evaluating PRE and POST herbicides was conducted in 2002 and 2003 in a producer's field near Bethel, $\mathrm{MO}\left(39^{\circ} 52^{\prime} \mathrm{N}, 92^{\circ} 0^{\prime} \mathrm{W}\right)$, with documented resistance to lactofen and acifluorfen [17]. The soil was a Putnam silt loam (fine, smectitic, and mesic vertic Albaqaulfs) with $26 \mathrm{~g} \mathrm{~kg}^{-1}$ organic matter and $\mathrm{pH}$ 6.2. The site was field-cultivated twice before applying PRE herbicides. Treatments were applied using a $\mathrm{CO}_{2}$ backpack sprayer calibrated to deliver $187 \mathrm{~L} \mathrm{ha}^{-1}$ at $138 \mathrm{kPa}$ with 8003 flat-fan nozzles (Spray Systems Co., Wheaton, IL). Environmental conditions and plant development at the time of application are reported in Table 1. Experiments were arranged as a randomized complete block with four replications in plots 3 by $12.2 \mathrm{~m}$. Visual control was rated on a scale of 0 (no injury) to $100 \%$ (complete plant death).
TABLE 1: Environmental conditions and plant size for preemergence and postemergence applications for field research in 2002 and 2003.

\begin{tabular}{lcc}
\hline Application & 2002 & 2003 \\
\hline Preemergence & & \\
$\quad$ Date & 19 April & 2 May \\
Air temperature $\left({ }^{\circ} \mathrm{C}\right)$ & 22 & 18 \\
Soil temperature $\left({ }^{\circ} \mathrm{C}\right)$ & 18 & 16 \\
Postemergence & & \\
Date & 6 June & 27 June \\
Height $(\mathrm{cm})$ & $5-25$ & $5-20$ \\
Leaf number & $6-10$ & $4-12$ \\
Population $\left(\right.$ no $\left./ \mathrm{m}^{2}\right)$ & $419-586$ & $382-528$ \\
Cloud cover $(\%)$ & 5 & 8 \\
Relative humidity $(\%)$ & 33 & 57 \\
Air temperature $\left({ }^{\circ} \mathrm{C}\right)$ & 30 & 25 \\
\hline
\end{tabular}

PRE herbicide treatments included flumioxazin applied at $72 \mathrm{~g}$ i ha ${ }^{-1}$, isoxaflutole at $70 \mathrm{gai} \mathrm{ha}^{-1}$, and sulfentrazone at $240 \mathrm{~g} \mathrm{ai} \mathrm{ha}^{-1}$. Isoxaflutole, a 4-hydroxyphenylpyruvate dioxygenase (HPPD) inhibiting herbicide, was used as a standard to compare to the protox-inhibiting herbicides flumioxazin and sulfentrazone. Visual ratings were recorded $28 \mathrm{~d}$ after treatment (DAT). Surviving plants were counted in 30 by $76 \mathrm{~cm}$ quadrats and percent stand reduction was calculated based on the nontreated control.

POST herbicide treatments included typical field application rates of acifluorfen at $420 \mathrm{~g} \mathrm{ai} \mathrm{ha}^{-1}$, atrazine at 1680 $\mathrm{g}$ ai ha ${ }^{-1}$, carfentrazone at $9 \mathrm{~g}$ ai ha ${ }^{-1}$, dicamba/diflufenzopyr at $290 \mathrm{~g} \mathrm{ai} \mathrm{ha}^{-1}$, flumiclorac at $30 \mathrm{gaiha}^{-1}$, fomesafen at $330 \mathrm{gaiha}^{-1}$, lactofen at $220 \mathrm{gaiha}^{-1}$, and mesotrione at $110 \mathrm{~g} \mathrm{ai} \mathrm{ha}^{-1}$. Visual control of waterhemp was recorded 21 DAT. Fifteen plants, approximately $10 \mathrm{~cm}$ tall, were randomly marked with plastic garden stakes in the center of each plot before applying the POST treatment. Five plants were harvested and their fresh weight recorded at 7, 14, and 21 DAT, but only data 21 DAT were reported.

2.2. General Methods for Greenhouse Experiments. Common waterhemp seed were collected from plants surviving a POST lactofen application at Bethel; seed from waterhemp known to be susceptible to protox-inhibiting herbicides also were used as a control population. Common waterhemp seeds were sown into $10-\mathrm{cm}$ diameter polypropylene containers and filled with field or potting soil. As seedlings emerged, they were thinned to one plant per container and grown under a 16 -h photoperiod at $30^{\circ} \mathrm{C}$. Water and fertilizer were added as needed via subirrigation. Overhead irrigation was applied following herbicide application for activation of soil persistent herbicides. All herbicide treatments were applied using a compressed air pressure system calibrated to deliver $187 \mathrm{~L} \mathrm{ha}^{-1}$ at $166 \mathrm{kPa}$ with 80015 nozzle tips. POST herbicides were applied when plants reached $10 \mathrm{~cm}$. Cultural methods were similar for all greenhouse research unless otherwise described. 
TABLE 2: Visual control and common waterhemp stand establishment 28 days after application of PRE herbicides in 2002 and 2003.

\begin{tabular}{|c|c|c|c|c|c|}
\hline \multirow{3}{*}{ Treatment } & \multirow{3}{*}{$\begin{array}{c}\text { Rate } \\
\text { g ai ha }{ }^{-1}\end{array}$} & \multicolumn{2}{|c|}{2002} & \multicolumn{2}{|c|}{2003} \\
\hline & & Control & Stand reduction & Control & Stand reduction \\
\hline & & \multicolumn{4}{|c|}{$\%$} \\
\hline Flumioxazin & 72 & 90 & 91 & 91 & 98 \\
\hline Sulfentrazone & 240 & 84 & 92 & 90 & 99 \\
\hline Isoxaflutole & 70 & 85 & 90 & 95 & 99 \\
\hline Nontreated & - & 0 & 0 & 0 & 0 \\
\hline $\operatorname{LSD}(P=0.05)$ & & 12 & 27 & 7 & 39 \\
\hline
\end{tabular}

\subsubsection{Multiple-Resistance Evaluation. Additional herbicides} were evaluated to identify whether the protox-resitant waterhemp biotype had multiple resistances to other herbicidal modes of action. Treatments included: atrazine at $1680 \mathrm{~g}$ ai ha $^{-1}$, glyphosate at $840 \mathrm{~g}$ ai ha $^{-1}$, imazethapyr at $70 \mathrm{~g} \mathrm{ai} \mathrm{ha}^{-1}$, and mesotrione at $110 \mathrm{~g} \mathrm{ai} \mathrm{ha}^{-1}$. Among protoxinhibiting herbicide treatments were applications of acifluorfen at $420 \mathrm{~g} \mathrm{ai} \mathrm{ha}^{-1}$, flumioxazin at $72 \mathrm{~g}$ ai ha $^{-1}$, fomesafen at $330 \mathrm{~g} \mathrm{hi} \mathrm{ha}^{-1}$, lactofen at $220 \mathrm{~g}_{\text {ai ha }}{ }^{-1}$, lactofen at $880 \mathrm{~g} \mathrm{i} \mathrm{ha}^{-1}$ (4 times normal use rate), and sulfentrazone at $240 \mathrm{~g}$ ai ha $^{-1}$. A protox-susceptible biotype of common waterhemp was treated with lactofen at $220 \mathrm{~g}$ ai ha ${ }^{-1}$. Plants were grown in a peat mixture potting soil (Pro-Mix, Hummert Intl., St. Louis, Mo.) as described above. Herbicide application conditions were as described above. Visual control ratings and plant heights were recorded at 3, 7, 10, 14, and 21 DAT; however, only 21 DAT data is presented. Heights and fresh weights were measured 21 DAT and corresponding height and fresh weight reductions (as a percentage of the control) were calculated. The experiment was arranged as a randomized complete block with four replications and repeated.

2.2.2. Herbicide Placement. Common waterhemp seeds from the protox resitant waterhemp biotype were planted in a Mexico silt loam (fine, smectitic, and mesic aeric Vertic Epiaqualfs) with $42 \mathrm{~g} \mathrm{~kg}^{-1}$ organic matter and $\mathrm{pH}$ 7.1. Soil texture was $8 \mathrm{~g} \mathrm{~kg}^{-1}$ sand, $74 \mathrm{~g} \mathrm{~kg}^{-1}$ silt, and $18 \mathrm{~g} \mathrm{~kg}^{-1}$ clay. The experiment was arranged as a 5 by 3 factorial, with five herbicide treatments (nontreated control, lactofen at $220 \mathrm{~g}$ ai ha $^{-1}$, acifluorfen at $420 \mathrm{~g}$ ai ha $^{-1}$, fomesafen at

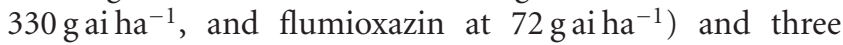
placements (foliar, soil, and foliar plus soil). There were four replications and the study was repeated. The foliar placement consisted of vermiculite placed over the soil and around the base of common waterhemp plants to prevent herbicide contact with the soil. The vermiculite was removed and discarded after herbicide application. The soil placement consisted of a $1.3 \mathrm{~cm}$ diameter polyvinyl chloride tube placed over the common waterhemp plant to prevent herbicide contact with plant tissues. For the foliar-plus-soil placement, plants were left in their natural state in pots. Visual control ratings and plant height were recorded at 3, 7, 10, 14, and 21 DAT. Plants were harvested and their fresh weights recorded (as a percentage of the control) 21 DAT.
2.2.3. Soil Persistence. A split-plot experimental design was used to determine the length of herbicide residual activity on the emergence suppression of common waterhemp. The main plot factor was PRE herbicide (nontreated control, acifluorfen at $420 \mathrm{~g}_{\text {ai ha }}^{-1}$, flumioxazin at $72 \mathrm{~g}$ ai ha ${ }^{-1}$, fomesafen at $330 \mathrm{~g}$ ai ha $^{-1}$, lactofen at $220 \mathrm{~g}_{\text {ai }} \mathrm{ha}^{-1}$, sulfentrazone at $240 \mathrm{~g}_{\text {ai ha }}^{-1}$, atrazine at $1680 \mathrm{~g}$ ai ha $^{-1}$, imazethapyr at $70 \mathrm{~g} \mathrm{ai} \mathrm{ha}^{-1}$, and isoxaflutole at $\left.70 \mathrm{gai} \mathrm{ha}^{-1}\right)$. The sub-plot factor was common waterhemp seeding date $(0,2,4$, and 6 weeks after application). Common waterhemp seeds were planted into a Mexico silt loam that was steam pasteurized at $60^{\circ} \mathrm{C}$ for 30 minutes to destroy viable common waterhemp seeds naturally present in the soil. The pasteurized soil was placed in 31 by $61 \mathrm{~cm}$ polypropylene containers, and each container was treated with a single herbicide. In each treated container, 100 common waterhemp seeds were counted and planted at intervals of $0,2,4$, and 6 weeks after herbicide application (WAHA). After each planting, $8.2 \mathrm{~mL}$ of water was applied to each treatment to ensure herbicide activation. At $28 \mathrm{~d}$ after each planting, visual control was rated and plant height measured, with height reduction calculated as a percentage of the control.

2.3. Statistical Analysis. All data were subjected to ANOVA and means separated using Fishers Protected LSD $(P=0.05)$. Field data were not combined due to a treatment-by-year interaction indicating significant variation in the common waterhemp population at Bethel. All greenhouse data were combined over experiments due to absence of interactions. Soil persistence data were fit to second-order polynomials using Microsoft Excel 2007 and reported for data averages because data were combined over experiments.

\section{Results and Discussion}

3.1. Field Experiment. Visual control of common waterhemp with flumioxazin, sulfentrazone, and isoxaflutole was $>84 \%$ and plant densities were reduced $>90 \%$ at 28 DAT (Table 2 ). Flumioxazin and sulfentrazone reportedly control broadleaf weeds up to 4 to 6 weeks after application (WAA) [22]. No differences were found in control between the PRE protoxinhibiting herbicides, flumioxazin or sulfentrazone, compared to the HPPD-inhibiting herbicide isoxaflutole. Shoup et al. [27] also observed that preemergence applications 
TABLE 3: Visual control and fresh weight reduction of common waterhemp population resistant to protox-inhibiting herbicides. Data were collected 21 days after treatment.

\begin{tabular}{|c|c|c|c|c|c|}
\hline \multirow{3}{*}{ Treatment $^{\mathrm{a}}$} & \multirow{3}{*}{ Rate } & \multicolumn{2}{|r|}{2002} & \multicolumn{2}{|r|}{2003} \\
\hline & & Control & Fresh weight reduction & Control & Fresh weight reduction \\
\hline & & \multicolumn{4}{|c|}{$\%$} \\
\hline Nontreated & & 0 & 0 & 0 & 0 \\
\hline Flumiclorac-pentyl + COC & $30 \mathrm{~g}$ ai $/ \mathrm{ha}+2.3 \mathrm{~L} / \mathrm{ha}$ & 26 & 64 & 0 & 34 \\
\hline Carfentrazone-methyl + NIS & $9 \mathrm{~g} \mathrm{ai} / \mathrm{ha}+0.25 \% \mathrm{v} / \mathrm{v}$ & 14 & 57 & 8 & 37 \\
\hline Lactofen + COC + DAS & $220+1.2 \mathrm{~L} / \mathrm{ha}+2.8 \mathrm{~kg} / \mathrm{ha}$ & 34 & 49 & 45 & 14 \\
\hline Acifluorfen + COC + DAS & $420+2.3 \mathrm{~L} / \mathrm{ha}+1.7 \mathrm{~kg} / \mathrm{ha}$ & 46 & 90 & 18 & 17 \\
\hline Fomesafen + COC + UAN & $330+1 \% \mathrm{v} / \mathrm{v}+2.5 \% \mathrm{v} / \mathrm{v}$ & 57 & 89 & 20 & 39 \\
\hline Mesotrione + COC + DAS & $110+1 \% \mathrm{v} / \mathrm{v}+9.5 \mathrm{~kg} / \mathrm{ha}$ & 99 & 99 & 68 & 72 \\
\hline Dicamba/diflufenzopyr + NIS + DAS & $290+0.25 \% \mathrm{v} / \mathrm{v}+2.8 \mathrm{~kg} / \mathrm{ha}$ & 72 & 78 & 87 & 83 \\
\hline Atrazine + COC & $1680 \mathrm{~g}$ ai $/ \mathrm{ha}+2.3 \mathrm{~L} / \mathrm{ha}$ & 56 & 100 & 37 & 42 \\
\hline $\operatorname{LSD}(P=0.05)$ & & 23 & 28 & 12 & 42 \\
\hline
\end{tabular}

${ }^{a}$ Abbreviations: DAS: diammonium sulfate $\left(\left(\mathrm{NH}_{4}\right)_{2} \mathrm{SO}_{4}\right)$; COC: crop oil concentrate; and NIS: nonionic surfactant; UAN: $28 \%$ urea ammonium nitrate.

of flumioxazin and sulfentrazone-controlled protox-resistant common waterhemp $95 \%$ and $92 \%$, respectively. Therefore, soil-active protox herbicides are a viable option for control of waterhemp that is resistant to foliar-active protox herbicides. However, these herbicides may select for protox-resistant biotypes similar to other research [28].

3.2. Postemergence Control. At 21 DAT, POST applications of fomesafen, acifluorfen, lactofen, flumiclorac, and carfentrazone-ethyl resulted in less than $60 \%$ visible control in 2002 and less than 50\% in 2003 (Table 3). In 2002, mesotrione, dicamba/diflufenzopyr, and atrazine resulted in 99,72 , and $56 \%$ visual control, respectively. However, in 2003, mesotrione, dicamba/diflufenzopyr, and atrazinecontrolled common waterhemp 68,87 , and $37 \%$, respectively. Differences in visual control and fresh-weight reductions were due to uniformly marked plants $(10 \mathrm{~cm}$ tall $)$ that were evaluated for fresh weight reduction and visual control was for the range of common waterhemp sizes (Table 1). Shoup et al. [12] observed increased common waterhemp injury with fomesafen compared to other POST protox herbicides such as lactofen and acifluorfen. Field results for 2002 (Table 3) were similar to other research [12], indicating increased common waterhemp control with fomesafen in comparison to lactofen, but in 2003 the opposite was observed. Atrazine-controlled common waterhemp less than $60 \%$ in both years; however, this is likely attributed to applications applied when weeds were $10 \mathrm{~cm}$ tall and exceeded the target size. Timely applications and coverage of high waterhemp populations with atrazine may be difficult because common waterhemp grows rapidly [29]. In 2003, control of waterhemp with mesotrione was less than $70 \%$. With recent documentations of resistance to glyphosate [25] and HPPD-inhibiting herbicides [30], greater focus on suppression of waterhemp with residual herbicides may be necessary for successful management.
3.2.1. Greenhouse Multiple-Resistance Evaluation. The protox herbicides lactofen (both rates), fomesafen, flumioxazin, acifluorfen, and sulfentrazone resulted in $<30 \%$ visual control of common waterhemp by 21 DAT (Table 4). Atrazine (PSII-inhibiting) and imazethapyr (ALS-inhibiting) control of common waterhemp was 27 and $0 \%$, respectively. These results indicate that the common waterhemp biotype at Bethel was most likely resistant to ALS, PSII, and protox herbicides. Patzoldt et al. [31] confirmed multiple resistances of common waterhemp to all three herbicide groups in Illinois. It is likely the Bethel biotype is multiresistant to ALSinhibitors and functionally resistant based upon treated size to atrazine. In 2003, the HPPD-inhibitor mesotrione was also ineffective with $<70 \%$ control of common waterhemp 21 DAT. Glyphosate was the only herbicide that controlled protox-resistant waterhemp. Lactofen applied to susceptible plants controlled this biotype. Height and fresh-weight reduction were similar to the visual control ratings. Recent research has reported HPPD-resistant common waterhemp in the Midwestern USA [30].

3.2.2. Greenhouse Herbicide Placement. Flumioxazin and fomesafen had $11 \%$ to $32 \%$ greater control of common waterhemp with a soil-plus-foliar herbicide placement compared to soil-only or foliar-only placement, but control remained less than $40 \%$ (Table 5). There was no difference in control among herbicide treatments with soilonly and foliar-only herbicide placements. Height and fresh-weight reduction results were similar to results with visual control. Flumioxazin and fomesafen had 11\% to $25 \%$ greater height reduction compared to lactofen or acifluorfen when soil-plus-foliar applied 21 DAT. Placement affected control of common waterhemp, though none of the treatments provided greater than $32 \%$ control or greater than $36 \%$ height or fresh weight reduction 21 DAT. 
TABLE 4: Visual response, height reduction, and fresh-weight reduction of common waterhemp $21 \mathrm{~d}$ after applicationin the greenhouse.

\begin{tabular}{|c|c|c|c|c|c|}
\hline Treatment $^{\mathrm{a}}$ & $\begin{array}{c}\text { Rate } \\
\text { g ai/ha }\end{array}$ & Resistant or nonresistant biotype & Control & $\begin{array}{c}\text { Height reduction } \\
\% \\
\end{array}$ & Fresh-weight reduction \\
\hline Nontreated & & Protox-resistant & 0 & 0 & 0 \\
\hline Glyphosate + DAS & 840 & Protox-resistant & 100 & 100 & 100 \\
\hline Lactofen + COC + DAS & 220 & Protox-resistant & 6 & 19 & 24 \\
\hline Lactofen + COC + DAS & 880 & Protox-resistant & 30 & 39 & 37 \\
\hline Sulfentrazone + DAS + COC & 240 & Protox-resistant & 8 & 30 & 28 \\
\hline Acifluorfen + COC + DAS & 420 & Protox-resistant & 10 & 25 & 29 \\
\hline Flumioxazin + COC + DAS & 72 & Protox-resistant & 19 & 29 & 36 \\
\hline Fomesafen + COC + DAS & 330 & Protox-resistant & 20 & 28 & 23 \\
\hline Imazethapyr + NIS & 70 & Protox-resistant & 0 & -17 & -30 \\
\hline Mesotrione + COC + DAS & 105 & Protox-resistant & 30 & 24 & 22 \\
\hline Atrazine $+\mathrm{COC}$ & 1680 & Protox-resistant & 27 & 32 & 36 \\
\hline Nontreated & & Nonresistant & 0 & 0 & 0 \\
\hline Lactofen + COC + DAS & 220 & Nonresistant & 100 & 100 & 100 \\
\hline $\operatorname{LSD}(P=0.05)$ & & & 19 & 21 & 22 \\
\hline
\end{tabular}

${ }^{a}$ Additives included crop-oil concentrate (COC) at $1.2 \mathrm{l} / \mathrm{ha}$, diammonium sulfate (DAS) at $2.8 \mathrm{~kg} / \mathrm{ha}$, and nonionic surfactant (NIS) at $0.25 \% \mathrm{v} / \mathrm{v}$.

TABle 5: The effect of herbicide placement on the response of protox herbicide-resistant common waterhemp. Criteria for evaluating common waterhemp included visual control, height reduction, and fresh-weight reduction $21 \mathrm{~d}$ after treatment.

\begin{tabular}{|c|c|c|c|c|c|}
\hline Treatment $^{\mathrm{a}}$ & $\begin{array}{c}\text { Rate } \\
\text { g ai/ha }\end{array}$ & Placement & Control & $\begin{array}{c}\text { Height reduction } \\
\%\end{array}$ & Fresh-weight reduction \\
\hline Nontreated & & Soil only & 0 & 0 & 0 \\
\hline Lactofen & 220 & Soil only & 0 & 8 & 6 \\
\hline Acifluorfen & 420 & Soil only & 0 & 12 & 13 \\
\hline Fomesafen & 330 & Soil only & 0 & 1 & 3 \\
\hline Flumioxazin & 72 & Soil only & 0 & 12 & 11 \\
\hline Nontreated & & Foliar only & 0 & 0 & 0 \\
\hline Lactofen & 220 & Foliar only & 13 & 13 & 14 \\
\hline Acifluorfen & 420 & Foliar only & 13 & 17 & 17 \\
\hline Fomesafen & 330 & Foliar only & 13 & 16 & 17 \\
\hline Flumioxazin & 72 & Foliar only & 15 & 18 & 16 \\
\hline Nontreated & & Soil + foliar & 0 & 0 & 0 \\
\hline Lactofen & 220 & Soil + foliar & 8 & 11 & 13 \\
\hline Acifluorfen & 420 & Soil + foliar & 17 & 18 & 19 \\
\hline Fomesafen & 330 & Soil + foliar & 24 & 29 & 33 \\
\hline Flumioxazin & 72 & Soil + foliar & 32 & 36 & 36 \\
\hline $\operatorname{LSD}(P=0.05)$ & & & 3 & 2 & 7 \\
\hline
\end{tabular}

${ }^{a}$ All treatments included diammonium sulfate at $2.8 \mathrm{~kg} / \mathrm{ha}$ and crop oil concentrate at $1.2 \mathrm{l} / \mathrm{ha}$.

3.2.3. Greenhouse Herbicide Persistence. Isoxaflutole, sulfentrazone, fomesafen, flumioxazin, and atrazine provided greater than $85 \%$ control of common waterhemp when seeds were planted at the time of application ( 0 week after application planting (WAHA)) (Figure 1). Lactofen and acifluorfen, which are primarily used postemergence, provided less waterhemp control for all seeding intervals after herbicide treatment compared to atrazine, sulfentrazone, isoxaflutole, fomesafen, or flumioxazin. The lack of common waterhemp control with imazethapyr can be attributed to the waterhemp biotype having resistance to ALS-inhibiting herbicides. Both visual control (Figure 1) and height reduction (Figure 2) of common waterhemp decreased as the planting date was delayed up to 6 WAHA. Among the protox herbicides with residual activity, the half-life of flumioxazin is shorter (11.917.5 days) in comparison to sulfentrazone and fomesafen, which have a half-life that ranges from 121 to 302 days and 100 days, respectively [22]. Isoxaflutole exhibited the 


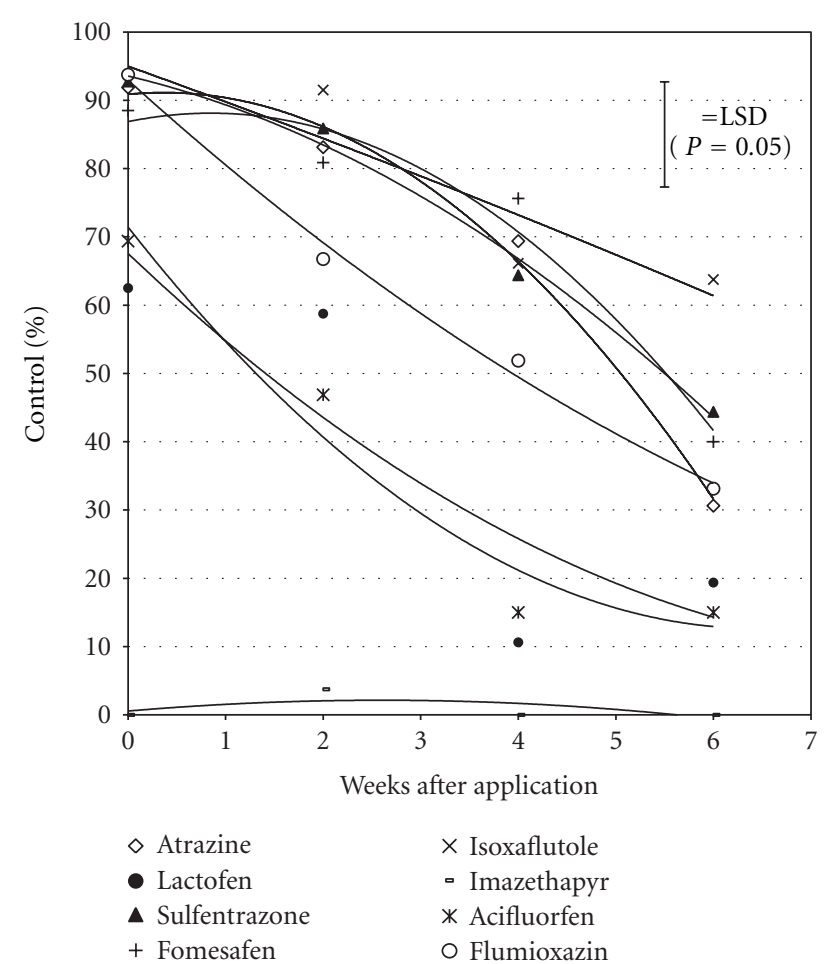

Figure 1: Preemergence control of common waterhemp with acifluorfen $\left(y=1.4063 x^{2}-18.188 x+71.438, R^{2}=0.96\right)$, flumioxazin $\left(y=0.5156 x^{2}-12.931 x+92.95, R^{2}=0.99\right)$, fomesafen $(y=$ $\left.-1.75 x^{2}+2.9625 x+86.862, R^{2}=0.96\right)$, lactofen $\left(y=0.7813 x^{2}-\right.$ $\left.13.563 x+67.562, R^{2}=0.76\right)$, sulfentrazone $\left(y=-0.8203 x^{2}-\right.$ $\left.3.4094 x+93.556, R^{2}=0.99\right)$, atrazine $\left(y=-1.875 x^{2}+1.375 x+\right.$ $\left.90.875, R^{2}=0.99\right)$, imazethapyr $\left(y=-0.2344 x^{2}+1.2188 x+0.5625\right.$, $\left.R^{2}=0.4\right)$, and isoxaflutole $\left(y=-0.0781 x^{2}-5.1312 x+94.987\right.$, $\left.R^{2}=0.85\right) 28$ days after planting when planted $0,2,4$, and 6 weeks after the herbicide application. The vertical line represents the LSD $(P=0.05)$.

greatest control of common waterhemp compared to protoxinhibiting herbicides at 6 WAHA. Fomesafen and sulfentrazone provided similar control of common waterhemp at all evaluation intervals, indicating that soil persistence with fomesafen was similar to that of the preemergence protox herbicides sulfentrazone and flumioxazin for management of protox-resistant common waterhemp.

\section{Conclusions}

Under field conditions, control of a biotype of common waterhemp that is resistant to protox herbicides exceeded 84\% with PRE applications of flumioxazin, sulfentrazone, and isoxaflutole, and was $>90 \%$ with POST applications of mesotrione in 2002. In the greenhouse, multiple resistances to POST imazethapyr was evident, and control with mesotrione and atrazine was poor, likely based upon the size of plants treated; however, common waterhemp was controlled with glyphosate. Soil-plus-foliar applications of fomesafen- and flumioxazin-controlled common waterhemp greater than soil-only or foliar-only treatments, but control,

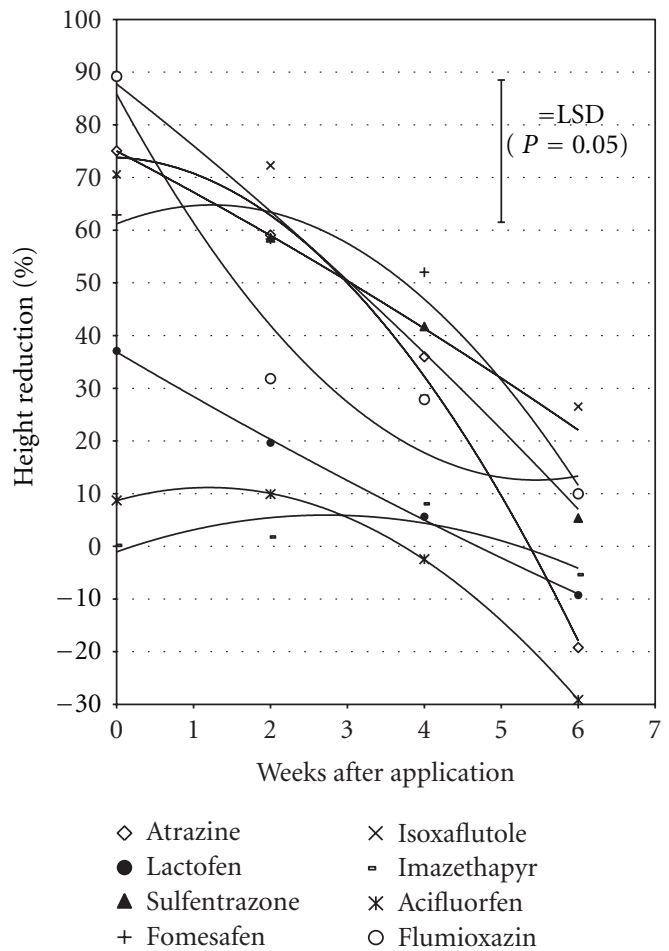

Figure 2: Preemergence height reduction of common waterhemp with acifluorfen at $420 \mathrm{~g} / \mathrm{ha}\left(y=-1.7456 x^{2}+4.1766 x+8.6638\right.$, $\left.R^{2}=0.99\right)$, flumioxazin at $72 \mathrm{~g} / \mathrm{ha}\left(y=2.4673 x^{2}-26.885 x+\right.$ $\left.85.82, R^{2}=0.94\right)$, fomesafen at $330 \mathrm{~g} / \mathrm{ha}\left(y=-2.3471 x^{2}+\right.$ $\left.5.8131 x+61.191, R^{2}=0.97\right)$, lactofen at $220 \mathrm{~g} / \mathrm{ha}\left(y=0.1593 x^{2}-\right.$ $\left.8.6097 x+36.875, R^{2}=0.99\right)$, sulfentrazone at $240 \mathrm{~g} / \mathrm{ha}(y=$ $\left.-0.3426 x^{2}-11.394 x+87.74, R^{2}=0.98\right)$, atrazine at $1680 \mathrm{~g} / \mathrm{ha}(y=$ $\left.-2.4501 x^{2}-0.595 x+73.805, R^{2}=0.99\right)$, imazethapyr at $70 \mathrm{~g} / \mathrm{ha}$ $\left(y=-0.9401 x^{2}+5.1214 x-1.0435, R^{2}=0.67\right)$, and isoxaflutole at $70 \mathrm{~g} / \mathrm{ha}\left(y=-0.2015 x^{2}-7.6133 x+75.009, R^{2}=0.80\right) 28$ days after planting when planted $0,2,4$, and 6 weeks after application. The vertical line represents the LSD $(P=0.05)$.

height, and fresh weight reduction was less than $40 \%$. In herbicide persistence evaluations, flumioxazin-, fomesafen, sulfentrazone-, atrazine-, and isoxaflutole-controlled common waterhemp greater than $85 \%$ when seed was sown 0 WAHA. None of the herbicide treatments provided greater than $70 \%$ visual control or $30 \%$ reduction in height of common waterhemp seeded 6 WAHA, indicating that sequential herbicide use may be necessary for season-long control. Effective management of protox herbicide-resistant common waterhemp must consider rotation of herbicides by mode of action to minimize the selection of additional resistant biotypes.

\section{Abbreviations:}

ALS: Acetolactate synthase

DAT: Days after treatment

DAS: Diammonium sulfate $\left(\left(\mathrm{NH}_{4}\right)_{2} \mathrm{SO}_{4}\right)$ 
COC: Crop oil concentrate

NIS: Non-ionic surfactant

Protox: Protoporphyrinogen oxidase

WAHA: Weeks after herbicide application.

\section{References}

[1] M. J. Horak and T. M. Loughin, "Growth analysis of four Amaranthus species," Weed Science, vol. 48, no. 3, pp. 347-355, 2000.

[2] L. M. Wax, "Pigweeds of the Midwest: distribution, importance and management," in Proceedings of the Intergrated Crop Management Conference, vol. 7, pp. 239-242, Iowa State University, Ames, Iowa, USA, 1995.

[3] M. Warmund, "Worst weeds 2010," http://ppp.missouri.edu/ newsletters/meg/archives/v16n11/a2.pdf, 2010.

[4] D. D. Buhler, K. A. Kohler, and R. L. Thompson, "Weed seed bank dynamics during a five-year crop rotation," Weed Technology, vol. 15, no. 1, pp. 170-176, 2001.

[5] D. D. Buhler and R. G. Hartzler, "Emergence and persistence of seed of velvetleaf, common waterhemp, woolly cupgrass, and giant foxtail," Weed Science, vol. 49, no. 2, pp. 230-235, 2001.

[6] R. G. Hartzler, D. D. Buhler, and D. E. Stoltenberg, "Emergence characteristics of four annual weed species," Weed Science, vol. 47, no. 5, pp. 578-584, 1999.

[7] J. C. Cordes and W. G. Johnson, "Common waterhemp interference in corn," in Proceedings of the North Central Weed Science Society, vol. 56, p. 132, 2001.

[8] A. G. Hager, L. M. Wax, E. W. Stoller, and G. A. Bollero, "Common waterhemp (Amaranthus rudis) interference in soybean," Weed Science, vol. 50, no. 5, pp. 607-610, 2002.

[9] A. G. Hager, W. L. Patzoldt, and P. J. Tranel, "Confirmation of PPO-inhibitor resistance in an Illinois waterhemp population," in Proceedings of the North Central Weed Science Society, vol. 57, p. 71, 2002.

[10] M. J. Foes, L. Liu, P. J. Tranel, L. M. Wax, and E. W. Stoller, "A biotype of common waterhemp (Amaranthus rudis) resistant to triazine and ALS herbicides," Weed Science, vol. 46, no. 5, pp. 514-520, 1998.

[11] A. S. Franssen, D. Z. Skinner, K. Al-Khatib, M. J. Horak, and P. A. Kulakow, "Interspecific hybridization and gene flow of ALS resistance in Amaranthus species," Weed Science, vol. 49, no. 5, pp. 598-606, 2001.

[12] D. E. Shoup, K. Al-Khatib, and D. E. Peterson, "Common waterhemp (Amaranthus rudis) resistance to protoporphyrinogen oxidase-inhibiting herbicides," Weed Science, vol. 51, no. 2, pp. 145-150, 2003.

[13] D. K. Wetzel, M. J. Horak, D. Z. Skinner, and P. A. Kulakow, "Transferal of herbicide resistance traits from Amaranthus palmeri to Amaranthus rudis," Weed Science, vol. 47, no. 5, pp. 538-543, 1999.

[14] D. D. Anderson, F. W. Roeth, and A. R. Martin, "Occurrence and control of triazine-resistant common waterhemp (Amaranthus rudis) in field corn (Zea mays)," Weed Technology, vol. 10, no. 3, pp. 570-575, 1996.

[15] J. R. R. Hinz and M. D. K. Owen, "Acetolactate synthase resistance in a common waterhemp (Amaranthus rudis) population," Weed Technology, vol. 11, no. 1, pp. 13-18, 1997.

[16] C. L. Sprague, E. W. Stoller, L. M. Wax, and M. J. Horak, "Palmer amaranth (Amaranthus palmeri) and common waterhemp (Amaranthus rudis) resistance to selected ALS-inhibiting herbicides," Weed Science, vol. 45, no. 2, pp. 192-197, 1997.
[17] J. Li, R. J. Smeda, K. A. Nelson, and F. E. Dayan, "Physiological basis for resistance to diphenyl ether herbicides in common waterhemp (Amaranthus rudis)," Weed Science, vol. 52, no. 3, pp. 333-338, 2004.

[18] S. O. Duke, "Protoporphyrinogen oxidase-inhibiting herbicides," Weed Science, vol. 39, pp. 465-473, 1991.

[19] M. Z. Huang, K. L. Huang, Y. G. Ren et al., "Synthesis and herbicidal activity of 2-(7-fluoro-3-oxo-3,4-dihydro-2Hbenzo[b] [1,4] oxazin-6-yl)isoindoline-1,3-diones," Journal of Agricultural and Food Chemistry, vol. 53, no. 20, pp. 7908$7914,2005$.

[20] H. J. Lee and S. O. Duke, "Protoporphyrinogen IX-oxidizing activities involved in the mode of action of peroxidizing herbicides," Journal of Agricultural and Food Chemistry, vol. 42, no. 11, pp. 2610-2618, 1994.

[21] U. B. Nandihalli, "Quantitative structure-activity relationships of protoporphyrinogen oxidase-inhibiting diphenyl ether herbicides," Pesticide Biochemistry and Physiology, vol. 43, no. 3, pp. 193-211, 1992.

[22] W. H. Ahrens, Ed., Herbicide Handbook, Weed Science Society of America, Champaign, Ill, USA, 8th edition, 2002.

[23] C. M. Mayo, M. J. Horak, D. E. Peterson, and J. E. Boyer, "Differential control of four Amaranthus species by six postemergence herbicides in soybean (Glycine max)," Weed Technology, vol. 9, no. 1, pp. 141-147, 1995.

[24] J. K. Sweat, M. J. Horak, D. E. Peterson, R. W. Lloyd, and J. E. Boyer, "Herbicide efficacy on four Amaranthus species in soybean (Glycine max)," Weed Technology, vol. 12, no. 2, pp. 315-321, 1998.

[25] T. R. Legleiter and K. W. Bradley, "Glyphosate and multiple herbicide resistance in common waterhemp (Amaranthus rudis) populations from Missouri," Weed Science, vol. 56, no. 4, pp. 582-587, 2008.

[26] N. E. Humberg, Ed., Herbicide Handbook, Weed Science Society of America, Champaign, Ill, USA, 6th edition, 1989.

[27] D. E. Shoup, K. Al-Khatib, and D. E. Peterson, "Control of protox-resistant common waterhemp in corn and soybean," in Proceedings of the North Central Weed Science Society, vol. 57, p. 16, 2002.

[28] J. S. Falk, D. E. Shoup, K. Al-Khatib, and D. E. Peterson, "Protox-resistant common waterhemp (Amaranthus rudis) response to herbicides applied at different growth stages," Weed Science, vol. 54, no. 4, pp. 793-799, 2006.

[29] B. A. Sellers, R. J. Smeda, W. G. Johnson, J. A. Kendig, and M. R. Ellersieck, "Comparative growth of six Amaranthus species in Missouri," Weed Science, vol. 51, no. 3, pp. 329-333, 2003.

[30] N. E. Hausman, S. Singh, P. J. Tranel et al., "Resistance to HPPD-inhibiting herbicides in a population of waterhemp (Amaranthus tuberculatus) from Illinois, United States," Pest Management Science, vol. 67, no. 3, pp. 258-261, 2011.

[31] W. L. Patzoldt, P. J. Tranel, and A. G. Hager, "A waterhemp (Amaranthus tuberculatus) biotype with multiple resistance across three herbicide sites of action," Weed Science, vol. 53, no. 1, pp. 30-36, 2005. 


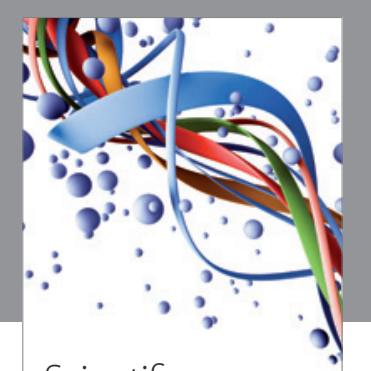

Scientifica
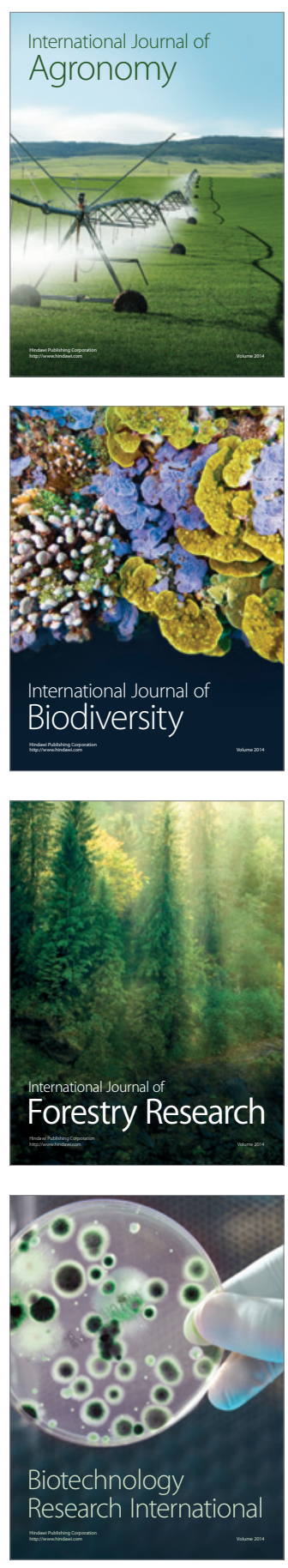
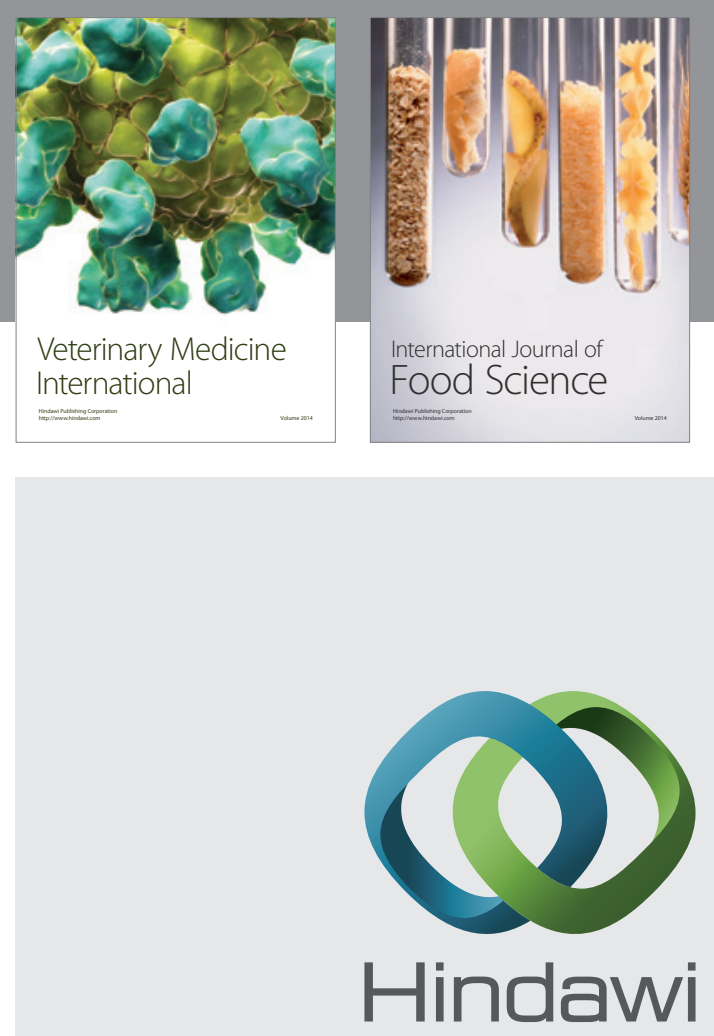

Submit your manuscripts at

http://www.hindawi.com
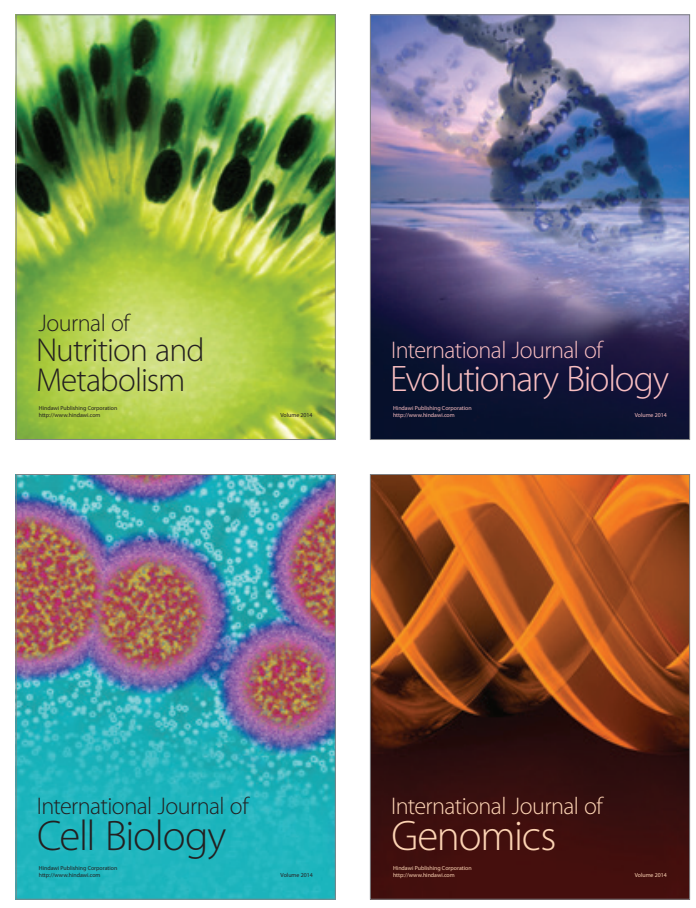
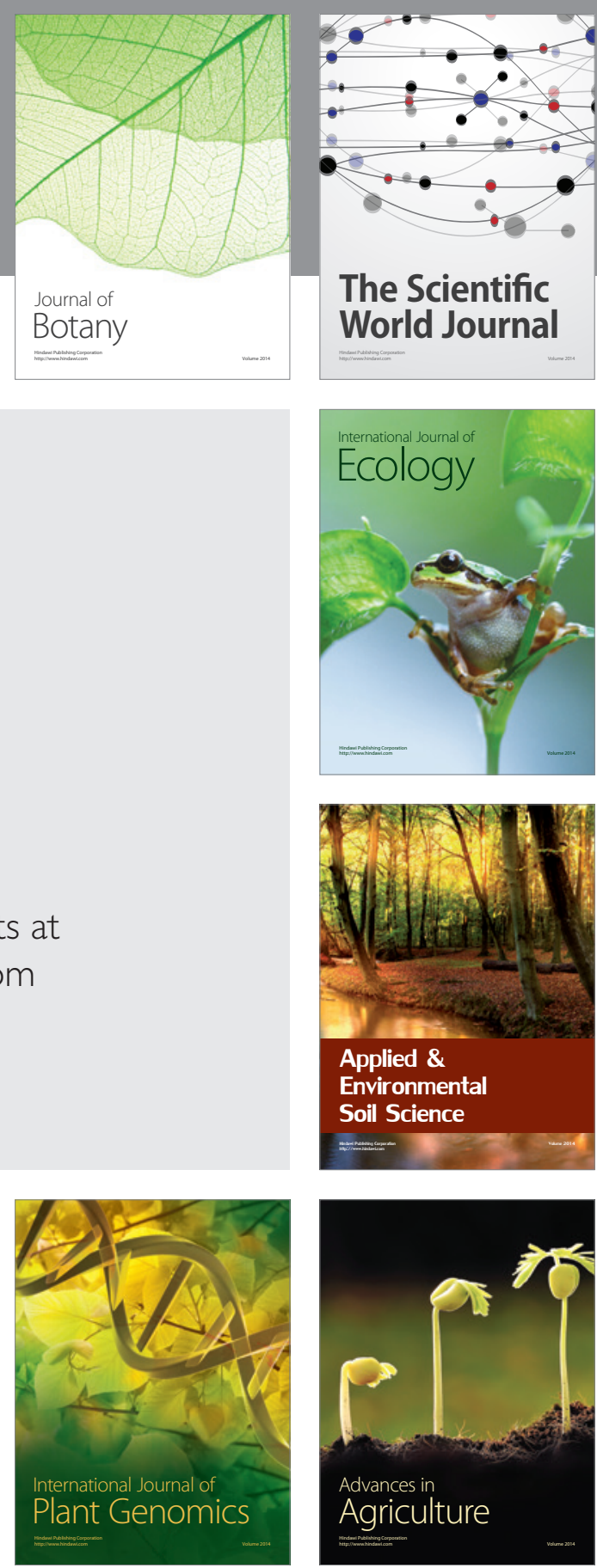

The Scientific World Journal
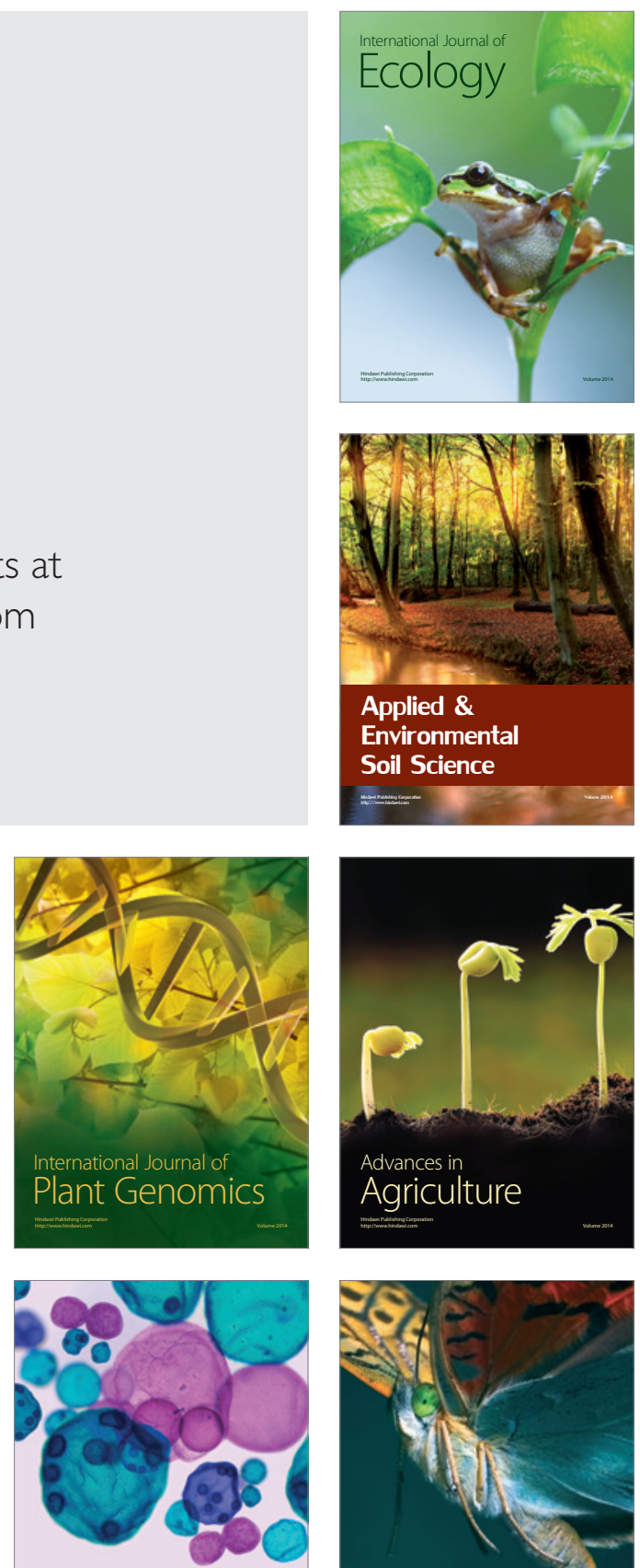

International Journal of Microbiology

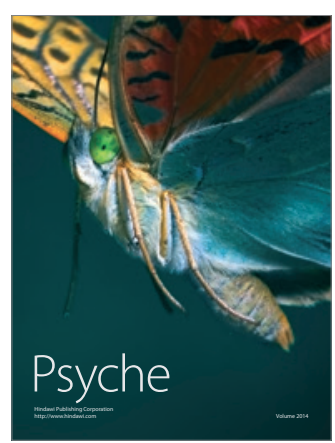

